\title{
Foliar application of liquid biofertilizer of brown alga Stoechospermum marginatum on growth, biochemical and yield of Solanum melongena
}

\author{
S. Sivasangari Ramya ${ }^{1} \cdot$ N. Vijayanand ${ }^{2} \cdot$ S. Rathinavel ${ }^{3}$
}

Received: 11 April 2014/Accepted: 18 April 2015/Published online: 20 May 2015

(C) The Author(s) 2015. This article is published with open access at Springerlink.com

\begin{abstract}
Background Seaweed extracts are used as nutrient supplements, biostimulants and or biofertilizers as an alternative to chemical fertilizers in agriculture. The study was set up to evaluate the biofertilizing efficiency of liquid extracts of brown marine alga Stoechospermum marginatum on growth, biochemical and yield of brinjal, a vegetable crop. To achieve the objectives, liquid extracts at different concentrations were prepared and applied as foliar spray on the brinjal seedlings raised in experimental pots maintained under natural conditions.

Results After 30 and 180 days, the growth and biochemical parameters and yield attributes were monitored, respectively. The results exhibited that shoot and root length, total fresh and dry weight, leaf area and the content of moisture, photosynthetic pigments, protein, amino acids, reducing sugar, ascorbic acid and nitrate reductase activity were found to be enhanced in the leaves of brinjal plants which received $1.5 \%$ of Stoechospermum marginatum extracts. Similarly, number of fruits and fruit weight were also increased at lower concentration only (1.5\%). In contrast, liquid extracts at high concentration $(5 \%)$ was
\end{abstract}

Electronic supplementary material The online version of this article (doi:10.1007/s40093-015-0096-0) contains supplementary material, which is available to authorized users.

N. Vijayanand

vijayapsac@gmail.com

1 Department of Biochemistry, Sri Sarada Niketan College for Women Amaravathipudur, Karaikudi, India

2 Department of Botany, Arumugam Pillai Seethai Ammal College, Tiruppattur, India

3 Centre for Research in Botany, Saraswathi Narayanan College (Autonomous), Madurai, India found to have inhibitory effect on brinjal plants as compared to the control sprayed with water.

Conclusions The study evidence that lower concentrations were found to show promoting effect on growth and productivity of brinjal plants. The fertilizing efficiency of liquid extracts of testing marine alga might me due to the presence of micro and macro nutrients, growth hormones and vitamins at preferential levels. It can be concluded that seaweed extracts could be used as eco-friendly liquid biofertilizer to substitute chemical fertilizer and also play a pivotal role in organic farming practices toward sustainable agriculture.

Keywords Seaweed extract · Liquid biofertilizer . Stoechospermum marginatum · Growth · Biochemical . Yield · Brinjal

\section{Introduction}

In modern agriculture, chemical fertilizers have degraded the fertility of soil making it acidic and rendering it unsuitable for raising crop plants. The intensive use of inputs has led to severe health and environmental hazards viz., soil erosion, water contamination, pesticide poisoning, falling ground water table, water logging and depletion of biodiversity. The practice of chemical farming has also put the long-run sustainability of Indian agriculture and the survival of the farming community at risk. In recent years, the use of natural seaweed as fertilizer has allowed for partial substitution of conventional synthetic fertilizer (Khan et al. 2009; Zodape et al. 2010). In addition, a number of commercial seaweed extract products are available for use in agriculture and horticulture. A number of seaweeds used a liquid fertilizer by applying them as foliar spray, soil drench, or in granular/ powder form as soil conditioners and manure (Thirumaran 
et al. 2009). These extracts are marketed as liquid biofertilizers because the chemical analyses of seaweeds and their extracts have revealed the presence of a wide variety of plant growth-promoting substances such as auxins, cytokinins and betaines (Khan et al. 2009).

Seaweeds are one of the important marine bio-resources which are nowadays termed as fantastically promising plants. Seaweeds and their derivatives are used in agriculture as potential plant growth regulators. Moreover, manures of seaweeds are used as a soil amendment in agriculture in many parts of the world (Eyras et al. 1998) and are an inexpensive local resource in coastal agricultural areas. Seaweed contains all major and minor plant nutrients, trace elements, vitamins, auxins and other bioactive substances. The growth promoting efficiency of fertilizing efficiency of extracts of several marine algae was evaluated in the cereals, pulses and vegetable crops (Kalidass et al. 2010; Sasikumar et al. 2011; Zodape et al. 2011; Bai et al. 2013; Parthiban et al. 2013; Kalaivanan et al. 2012; Hernández-Herrera et al. 2014). An attempt has been made to assess the biofertilizing potential of liquid extracts of marine brown alga Stoechospermum marginatum on important vegetable crop Solanum melongena.

\section{Materials and methods}

\section{Preparation of liquid extracts of seaweeds}

The marine alga Stoechospermum marginatum (C.Agardh) Kützing 1843:339 was collected from Mandapam (Lat $9^{\circ}$ $45^{\prime} \mathrm{N}$; Long $79^{\circ} 15^{\prime}$ E) located in South east coast of Tamil Nadu (Supplementary Fig. 1). The alga was brought to the laboratory and washed thoroughly in tap water for 3 or 4 times to remove all epiphytes, sand particles and associated fauna. The wet weight of sample of collected algal samples was taken and shade dried. After shade drying, it was cut into small pieces and kept in hot air oven for one day at $60{ }^{\circ} \mathrm{C}$. Then the dried sample of seaweed $(1 \mathrm{~kg})$ was further made into small pieces and powdered. The powdered sample of seaweed was mixed with water (20 litres) in the proportion of 1:20. Then it was boiled for one hour. After one hour, the mixture was squeezed and filtered through muslin cloth (Bhosle et al. 1975). The obtained extract was designated as stock solution and was used to prepare different concentrations viz; $0.5,1.0,1.5,2.0,2.5$ and $5.0 \%$ by mixing appropriate proportions of seaweed liquid extract (LE) with sterilized distilled water.

\section{Preparation of pot study}

Healthy seeds of brinjal plants (Variety CO-2, accession number-EG 203) were purchased from Agriculture
College and Research Institute, Madurai. They were surface sterilized with $0.1 \%$ mercuric chloride and then sown in earthenware pots $(9 \mathrm{~cm}$ dia) filled with a sterilized standard soil mix supplemented with sufficient quantity of NPK. Ten seeds were sowed in each pot. The seed to seed distance in pot was maintained at $3-5 \mathrm{~cm}$ and pots were watered regularly. After 10 days, potted plants were treated with different concentrations of SLE in the form of foliar spray. About $50 \mathrm{ml}$ of different concentrations of extracts was applied at intervals of 3 days. In treating plants, growth parameters viz., shoot length, root length, total height, total fresh and dry weight, leaf area, moisture content and relative water content were determined. Photosynthetic pigments (Arnon 1949), protein content (Lowry et al. 1951), reducing sugar (Nelson 1944), ascorbic acid (Roe 1954) and nitrate reductase activity (Jaworski et al. 1971) were assessed in the leaves of treated plants. Similarly, yield parameters such as number of fruits and fruit weight were also observed. Growth and biochemical parameters were recorded in 30-day-old treated and control plants. After 70 days, yield characters were observed. Routinely, the brinjal plants irrigated with water alone served as control. All pot experiments were done in four replicates each under natural uniform conditions.

\section{Physico-chemical and hormone analyses of seaweed extracts of Stoechospermum marginatum}

The physical observations such as colour and $\mathrm{pH}$ were made using standard methods. The presence of elements such as copper, manganese, zinc, iron, potassium, magnesium, cobalt and sodium were estimated using Atomic Absorption Spectrophotometer (Humpshires 1956). Further, liquid extract of seaweed was also subjected for estimation of auxin (Gordon and Paleg 1957), gibberellin (Graham and Henderson 1961) and cytokinin (Syono and Torrey 1976) using standard methods.

\section{Statistical analysis}

Data were subjected to one-way ANOVA and means were separated by Duncan's test $(P<0.05, n=5)$. Statistical analysis was carried out using IRRISTAT ver. 4.0 (IRRI, Manila, Phillipines) (Duncan 1965).

\section{Results and discussion}

\section{Physio chemical analysis of liquid extracts of S. marginatum}

The mineral analyses of liquid extract of our experimental brown marine alga revealed the presence of potassium 
Table 1 Physio-chemical and hormone analyses of liquid extract of S. marginatum

\begin{tabular}{ll}
\hline Physical parameters & \\
Colour & Brown \\
$\mathrm{pH}$ & 6.3 \\
Chemical parameters & \\
Copper & 3.014 \\
Manganese & 1.53 \\
Zinc & 1.58 \\
Iron & 0.500 \\
Potassium & 1.070 \\
Magnesium & 17.31 \\
Cobalt & 0.103 \\
Sodium & 5.77 \\
Growth hormones & \\
Auxin & 3.5 \\
Cytokinin & 9.2 \\
Gibberellin & 5.5 \\
\hline
\end{tabular}

All the parameters given are in $\mathrm{mg} / \mathrm{L}$ except colour and $\mathrm{pH}$

(1.070 mg/l), copper (3.014 mg/l), manganese $(1.53 \mathrm{mg} / \mathrm{l})$, zinc $(1.58 \mathrm{mg} / \mathrm{l})$, iron $(0.50 \mathrm{mg} / \mathrm{l})$, cobalt $(0.103 \mathrm{mg} / \mathrm{l})$, sodium $(5.77 \mathrm{mg} / \mathrm{l})$ and magnesium $(17.31 \mathrm{mg} / \mathrm{l})$ in appreciable level. Among the elements estimated, magnesium $(17.31 \mathrm{mg} / \mathrm{l})$ was found to be abundant in the extract. Similarly, in case of phytohormone analysis, cytokinin $(9.2 \mathrm{mg} / \mathrm{l})$ was found to be more when compared to auxin (3.5 mg/l) and gibberellins (5.5 mg/l) (Table 1).

The presence of phytohormones is in accordance with the earlier findings that reported auxins in the extracts of Ascophyllum nodosum (Sanderson and Jameson 1986) and cytokinins in the extracts of Ulva sp. (Sekar et al. 1995).

\section{Growth parameters of brinjal plants}

In next experiments, we applied liquid extracts of $S$. marginatum on brinjals. The results have shown that extracts generally increased the rate of growth and physiology of plant objects. Growth parameters such as total height (30\%), total fresh (150\%) and dry weight (125\%), leaf area $(61 \%)$ and moisture content $(56 \%)$ were enhanced when $1.5 \%$ of $S$. marginatum was given to brinjal plants. Higher concentrations (above $1.5 \%$ ) were found to show retarding effect on all the growth parameters (Table 2; Figs. 1 and 2).

Plants treated with different seaweed extracts exhibited wide range of responses that have been well documented in a number of reviews. In particular, seaweed extract concentrations were found to be effective in Brassica nigra (Kalidass et al. 2010), Abelmoschus esculentus (Sasikumar et al. 2011), Lycopersicon esculentum (Zodape et al. 2011), Vigna radiata (Bai et al. 2013; Parthiban et al. 2013), Vigna mungo (Kalaivanan et al. 2012), Solanum lycopersicum (Hernández-Herrera et al. 2014), Mangifera indica (Ahmed et al. 2013) and Fagopyrum esculentum (Anisimov et al. 2013). On the contrary, it has also been reported that concentration at $20 \%$ of brown alga Sargassum wightii (Jothinayagi and Anbazhagan 2009) and red alga Rosenvingea intricata (Thirumaran et al. 2009) promoted shoot length, root length, fresh and dry weight of Abelmoschus esculenthus and Cyamopsis tetragonolaba, respectively. Growth enhancement by seaweed extracts may be due to components such as macro and micro elements, amino acids, vitamins, cytokinins, auxins and abssisic acid (ABA)-like growth substances which affect cellular metabolism in treated plants leading to enhanced growth and crop yield (Ordog et al. 2004; Durand et al. 2003). Similarly, in our study, the increased growth of brinjal plants could be associated with the occurrence of some growth promoting substances present in the seaweed extract of $S$. marginatum as in other macro algal extract (Mooney and Van Staden 1986). The growth hormones play an imperative role in enhancement of cell size and cell division and together they complement each other as cytokinins are effective in

Table 2 Influence of liquid extracts of Stoechospermum marginatum on growth characteristics of brinjal

\begin{tabular}{|c|c|c|c|c|c|c|c|}
\hline $\begin{array}{l}\text { Seaweed extract } \\
\text { treatments }\end{array}$ & $\begin{array}{l}\text { Shoot length } \\
(\mathrm{cm})\end{array}$ & $\begin{array}{l}\text { Root length } \\
(\mathrm{cm})\end{array}$ & $\begin{array}{l}\text { Total height } \\
(\mathrm{cm})\end{array}$ & $\begin{array}{l}\text { Total fresh wt } \\
(\mathrm{mg})\end{array}$ & $\begin{array}{l}\text { Total dry wt } \\
(\mathrm{mg})\end{array}$ & $\begin{array}{l}\text { Leaf Area } \\
\left(\mathrm{mm}^{2}\right)\end{array}$ & $\begin{array}{l}\text { Moisture content } \\
(\%)\end{array}$ \\
\hline Control & $8.725 b$ & $12.250 \mathrm{a}$ & $20.00 \mathrm{ab}$ & $1.015 \mathrm{a}$ & $0.400 \mathrm{a}$ & $42.115 b$ & $41.533 \mathrm{a}$ \\
\hline $0.5 \%$ & $9.325 b$ & $13.050 \mathrm{ab}$ & $21.400 \mathrm{bc}$ & $1.130 \mathrm{bc}$ & $0.492 b$ & $44.183 b$ & $54.685 \mathrm{bc}$ \\
\hline $1.0 \%$ & $10.000 \mathrm{c}$ & $13.400 \mathrm{bc}$ & $23.33 b c$ & $1.620 \mathrm{de}$ & $0.620 \mathrm{c}$ & $50.790 \mathrm{c}$ & $63.645 \mathrm{bc}$ \\
\hline $1.5 \%$ & $11.400 \mathrm{~cd}$ & $15.250 \mathrm{~d}$ & $26.65 b c$ & $2.595 \mathrm{f}$ & $0.962 \mathrm{~d}$ & $68.165 d$ & $64.825 \mathrm{c}$ \\
\hline $2.0 \%$ & $10.300 \mathrm{c}$ & $14.450 \mathrm{~cd}$ & $24.750 \mathrm{c}$ & $1.800 \mathrm{e}$ & $0.605 \mathrm{c}$ & $58.400 \mathrm{~d}$ & $64.808 c$ \\
\hline $2.5 \%$ & $8.950 \mathrm{~b}$ & $14.200 \mathrm{~cd}$ & $23.150 \mathrm{bc}$ & $1.365 \mathrm{~cd}$ & $0.515 b$ & $43.425 b$ & $53.720 \mathrm{~b}$ \\
\hline $5.0 \%$ & $6.425 \mathrm{a}$ & $12.300 \mathrm{a}$ & $18.725 \mathrm{a}$ & $0.915 \mathrm{ab}$ & $0.400 \mathrm{a}$ & $35.450 \mathrm{a}$ & $55.785 \mathrm{bc}$ \\
\hline
\end{tabular}

Means sharing within the rows are significantly different $(P \leq 0.05$ level $)$

Different letters followed in each row are statistically significant based on DMRT 

extract of Stoechospermum marginatum on the total plant height of brinjal
Fig. 1 Influence of liquid

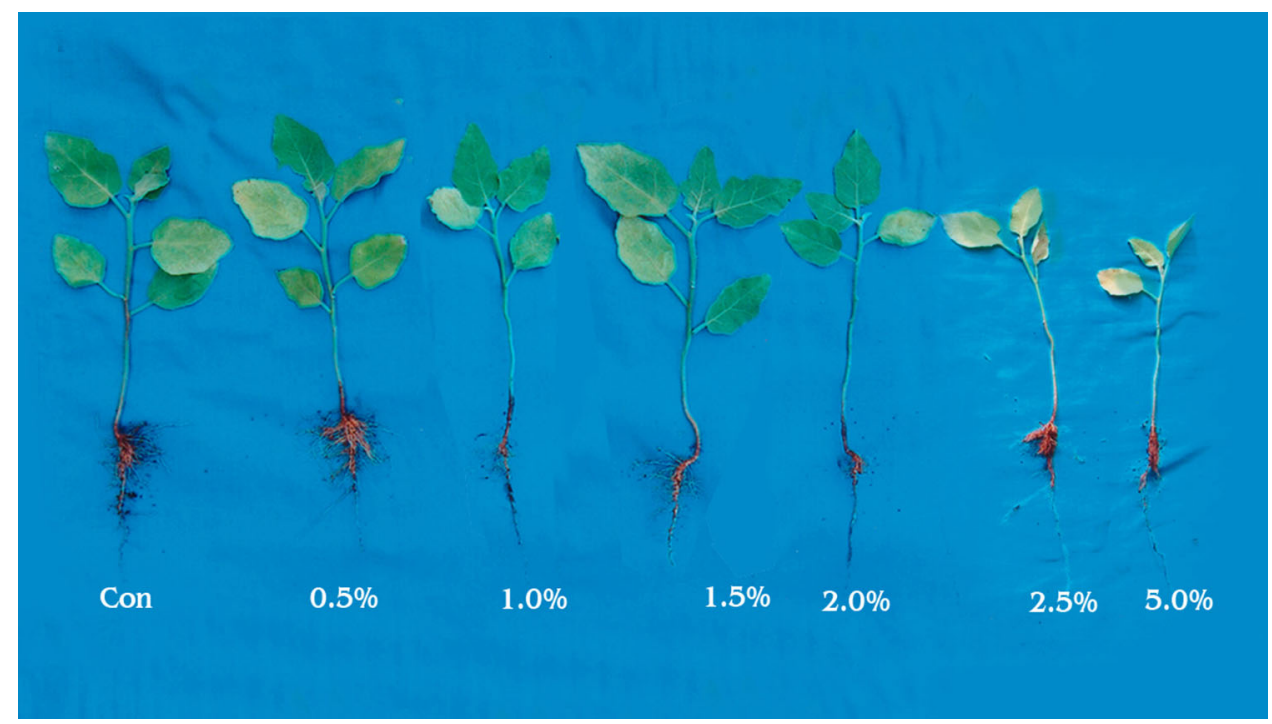

Fig. 2 Influence of liquid extract of Stoechospermum marginatum on the leaf area of brinjal

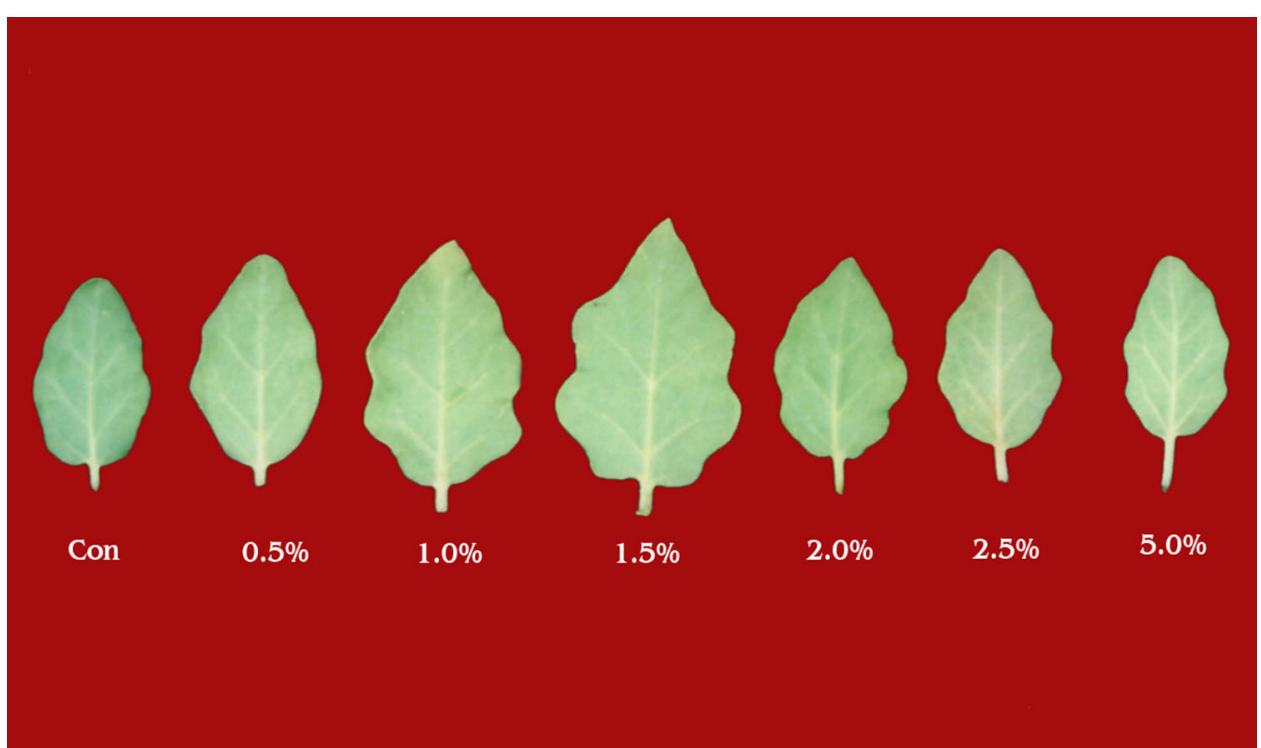

shoot formation and auxin in root development, while micronutrients improve soil health.

\section{Biochemical characteristics of brinjal plants}

In brinjal plants, there was a noticeable increase in biochemical parameters when $1.5 \%$ of seaweed liquid extract of $S$. marginatum applied to brinjal plant. The content of total chlorophyll pigments, (77\%), protein $(38 \%)$, reducing sugar $(201 \%)$ and ascorbic acid $(36 \%)$ and nitrate reductase activity $(159 \%)$ was enhances when the brinjal plants were treated with SLE at $0.5,1.0$ and $1.5 \%$ concentrations of $S$. marginatum (Table 3). However, steep decline was recorded in plants that received 2.0, 2.5 and $5.0 \%$ of $S$. marginatum extracts.
This is in accordance with the earlier reports that lower concentrations of seaweed extracts enhanced the biochemical constituents in Cajanus cajan (Erulan et al. 2009), Brassica nigra (Kalidass et al. 2010), Citrullus lanatus (Abdel-Mawgoud et al. 2010), Trigonella foenumgraecum (Pise and Sabale 2010), Solanum melongena (Bozorgi 2012) and Abelmoschus esculentus (Sasikumar et al. 2011). In our study, reducing sugar was found to be increased twofold when $1.5 \%$ of S. marginatum was given to brinjal plants. The increase in reducing sugar $(201 \%)$ may be due to the presence of magnesium (Table 1) which could have triggered chlorophyll synthesis and thereby subsequently increasing the photosynthetic rate in the plants. The increase in photosynthetic pigments may be also be due to the presence of betaines (Blunden et al. 
Table 3 Influence of liquid extract of Stoechospermum marginatum on biochemical characteristics of brinjal

\begin{tabular}{|c|c|c|c|c|c|c|c|}
\hline $\begin{array}{l}\text { Seaweed extract } \\
\text { treatments }\end{array}$ & $\begin{array}{l}\text { Chl-a (mg/g/ } \\
\text { fr.wt) }\end{array}$ & $\begin{array}{l}\text { Chl-b (mg/ } \\
\text { g/fr.wt) }\end{array}$ & $\begin{array}{l}\text { Total chlorophyll } \\
\text { (mg/g/fr.wt) }\end{array}$ & $\begin{array}{l}\text { Protein (mg/ } \\
\text { g/fr.wt) }\end{array}$ & $\begin{array}{l}\text { Reducing sugar } \\
\text { (mg/g/fr.wt) }\end{array}$ & $\begin{array}{l}\text { Ascorbic acid } \\
\text { (mg/g/fr.wt) }\end{array}$ & $\begin{array}{l}\text { NRA }(\mu \text { moles } \\
\left.\mathrm{No}^{-2} / \mathrm{gm} \mathrm{fr.wt} / \mathrm{hr}\right)\end{array}$ \\
\hline Con & $0.5225 \mathrm{a}$ & $0.4200 \mathrm{a}$ & $0.9425 \mathrm{a}$ & $19.200 \mathrm{~b}$ & $41.650 \mathrm{a}$ & $0.568 \mathrm{a}$ & $0.820 \mathrm{a}$ \\
\hline $0.5 \%$ & $0.6500 \mathrm{a}$ & $0.4450 \mathrm{~b}$ & $1.095 \mathrm{a}$ & $24.550 \mathrm{~b}$ & $55.850 \mathrm{~b}$ & $0.656 \mathrm{ab}$ & $1.090 \mathrm{~b}$ \\
\hline $1.0 \%$ & $0.6650 \mathrm{ab}$ & $0.515 \mathrm{c}$ & $1.180 \mathrm{c}$ & $28.250 \mathrm{c}$ & $62.650 \mathrm{c}$ & $0.700 \mathrm{c}$ & $1.635 \mathrm{~d}$ \\
\hline $1.5 \%$ & $0.975 \mathrm{~d}$ & $0.710 \mathrm{~d}$ & $1.685 \mathrm{~d}$ & $33.30 \mathrm{~d}$ & $84.10 d$ & $0.775 b c$ & $2.125 \mathrm{e}$ \\
\hline $2.0 \%$ & $0.805 \mathrm{c}$ & $0.530 \mathrm{~b}$ & $1.335 b$ & $26.625 b c$ & $66.80 \mathrm{c}$ & $0.637 \mathrm{ab}$ & $1.725 \mathrm{~d}$ \\
\hline $2.5 \%$ & $0.650 \mathrm{c}$ & $0.442 b$ & $1.192 \mathrm{a}$ & $21.350 \mathrm{a}$ & $51.50 \mathrm{~b}$ & $0.593 \mathrm{a}$ & $1.345 \mathrm{c}$ \\
\hline $5.0 \%$ & $0.590 \mathrm{~b}$ & $0.315 \mathrm{a}$ & $1.052 \mathrm{a}$ & $19.90 \mathrm{a}$ & $42.10 \mathrm{a}$ & $0.582 \mathrm{a}$ & $0.970 \mathrm{ab}$ \\
\hline
\end{tabular}

Means sharing within the rows are significantly different $(P \leq 0.05$ level $)$

Different letters followed in each row are statistically significant based on DMRT

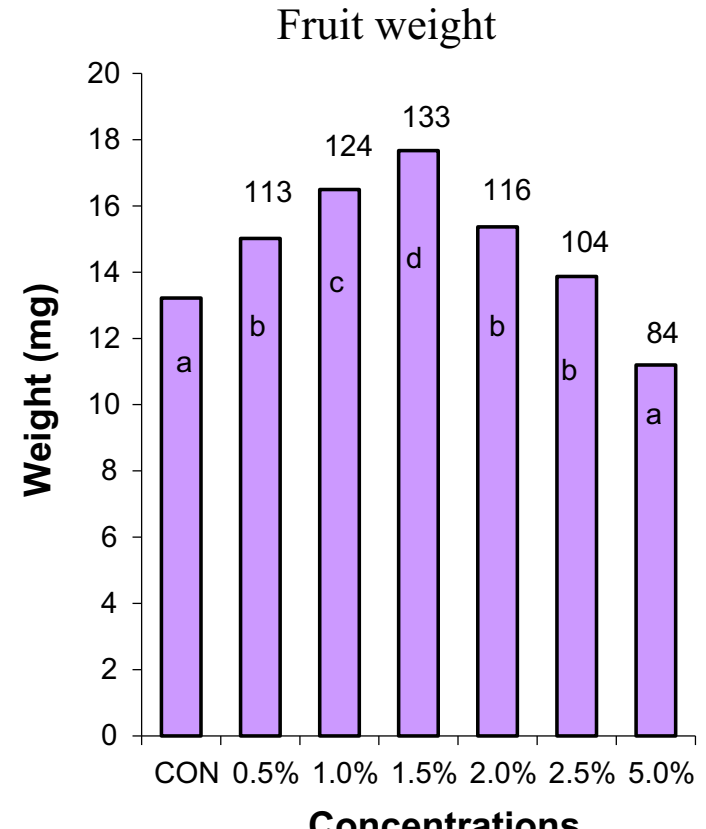

Concentrations

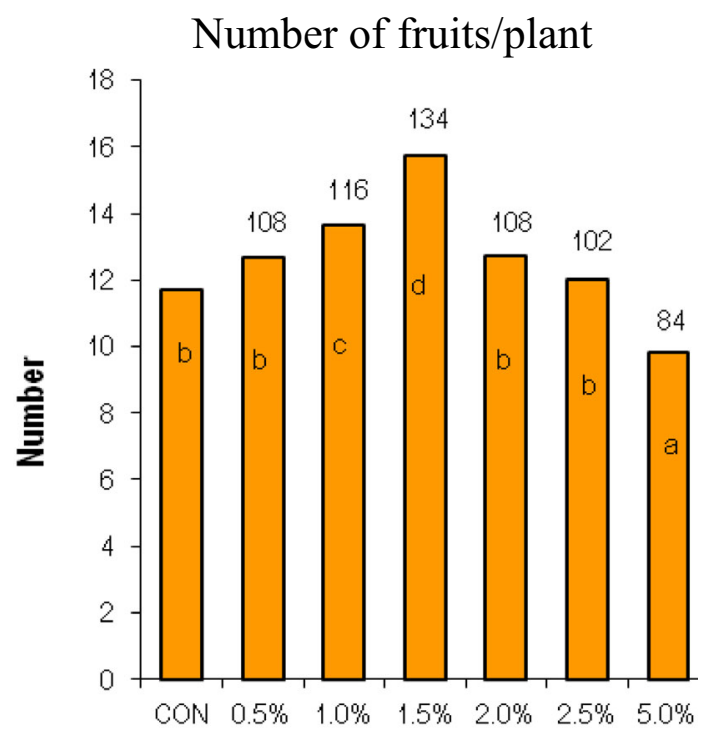

Concentrations
Fig. 3 Influence of liquid extracts of Stoechospermum marginatum on fruit weight and number of fruits/plant of brinjal. Numbers present above each bar are percent over control. Different letters inside each bar is statistically significant based on DMRT $(P \leq 0.05$ level $)$

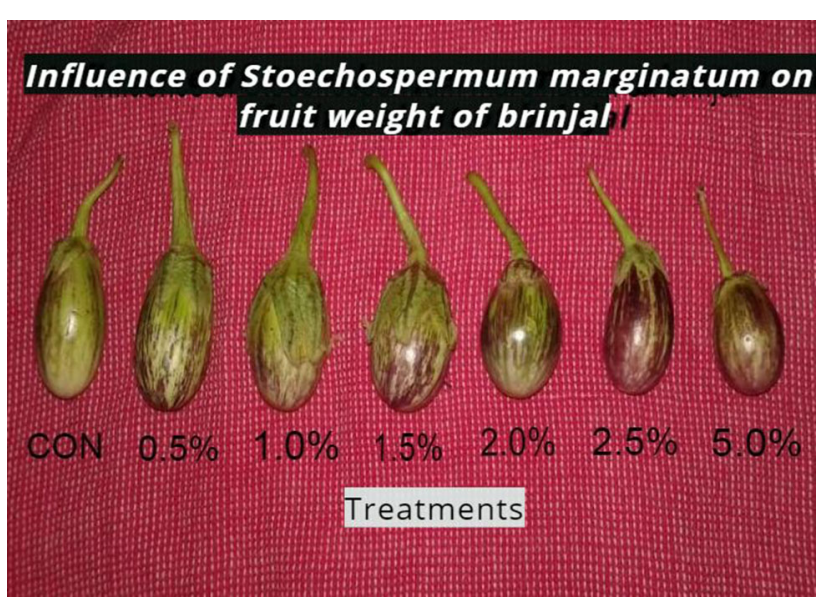

Fig. 4 Influence of liquid extract of Stoechospermum marginatum on the fruit weight of brinjal

1997), increase in number and size of the chloroplast and better grana development (Atzmon and Van Staden 1994) in the SLE-treated plants. Moreover, the increase in the protein content and nitrate reductase activity at lower concentrations of SLE confirmed the efficiency of foliar spray as it enhanced the absorption of most of the necessary elements by the seedlings. The increase in chlorophyll content could also be a result of reduction in chlorophyll degradation, which might be caused in part by betaines in the seaweed liquid extract (Whapman et al. 1993). In addition, in a study, $1 \%$ Ulva lactuca extract along with $50 \%$ recommended rate of chemical fertilizers enhanced the content of protein, carbohydrate and lipid in Tagetus erecta (Sridhar and Rengasamy 2010). However, it has been reported that seaweed liquid fertilizer at $10 \%$ extracted from brown alga Sargassum wightii increased the content of photosynthetic pigments, protein and total 
Table 4 Influence of liquid extracts of Stoechospermum marginatum on fruit weight and number of fruits/plant of brinjal

\begin{tabular}{lllllrrr}
\hline Seaweed treatments & Control & $0.5 \%$ & $1.0 \%$ & $1.5 \%$ & $2.0 \%$ & $2.5 \%$ & $5.0 \%$ \\
\hline Fruit weight $(\mathrm{g})$ & $13.22 \pm 0.14 \mathrm{a}$ & $15.02 \pm 0.13 \mathrm{~b}$ & $16.5 \pm 0.34 \mathrm{c}$ & $17.67 \pm 0.34 \mathrm{~d}$ & $15.37 \pm 0.30 \mathrm{~b}$ & $13.87 \pm 0.09 \mathrm{~b}$ & $11.20 \pm 0.30 \mathrm{a}$ \\
Number of fruits & $11.72 \pm 0.25 \mathrm{~b}$ & $12.70 \pm 0.26 \mathrm{~b}$ & $13.62 \pm 0.10 \mathrm{c}$ & $15.75 \pm 0.26 \mathrm{~d}$ & $12.75 \pm 0.20 \mathrm{~b}$ & $12.0 \pm 0.14 \mathrm{~b}$ & $9.8 \pm 0.10 \mathrm{a}$ \\
\hline
\end{tabular}

Results are mean $\pm \mathrm{SD}(n=5)$. Means sharing within the rows are significantly different $(P \leq 0.05$ level $)$

Different letters followed in each row statistically significant based on DMRT

sugars in Vigna radiata (Sivasankari et al. 2006) and SLE of Rosenvingea intricata at $20 \%$ enhanced the photosynthetic pigments and carotenoids in Cyamopsis tetragonoloba (Thirumaran et al. 2009).

\section{Yield attributes of brinjal plants}

In many crops, yield is associated with the number of flowers at maturity. As the onset and development of flowering and the number of flowers produced are linked to the developmental stage of plants, seaweed extracts probably encourage flowering by initiating robust plant growth (Khan et al. 2009). In our experiments, different concentrations of $S$. marginatum extracts showed differential responses in the yield characters also. Significant increase in number of flowers $(34 \%)$ and fruit weight $(33 \%)$ was noticed when $1.5 \%$ of S. marginatum was given as foliar spray. (Fig. 3a, b). However, decrease in number and weight of the fruits was observed in higher concentrations (above $1.5 \%$ ) Fig. 4.

Seaweed extract at low concentrations not only increase the vegetative growth of the plant but also triggers the early flowering and fruiting in crops. In our study, reports showed that treatment of Ablemoschus esculentus with seaweed extract increased the length (31.7\%), diameter (18.2\%) and yield (37.4\%) of fruits as compared to (Zodape et al. 2008). The liquid extract of Hypnea musciformis, Laurencia obtusa, Padina tetrastromatica and Stoechospermum mariginatum acted as a biostimulant to increase the productivity and quality of tea (Thevanathan et al. 2005). Zodape et al. (2011) observed that foliar application of liquid extracts of Kappaphycus alvarezii promoted the yield potency of Lycopersicon esculentum, a vegetable crop. Bai et al. (2013) applied the liquid extract of Padina pavonia and got maximum yield of pulses. Moreover, in potato, Siddagangaiah et al. (2010) recorded that per cent tuber yield, tuber dry matter content, dry weight of haulms and tubers were enhanced when potato plants received $0.5 \%$ and $0.4 \%$ of Phyton-T, a commercial seaweed extracts. Yield increase in seaweed-treated plants is thought to be associated with the hormonal substances present in the extracts, especially cytokinins (Featonby-Smith and Van Staden 1984). Cytokinins in vegetative plant organs are associated with nutrient partitioning, whereas in reproductive organs, high levels of cytokinins may be linked with nutrient mobilization. It may also be attributed with the process of fruit ripening that generally causes an increase in transport of nutrient resources. Moreover, the phytohormones play a significant role in retention of flowers and fruits during the reproductive phase of crops and thus promoted crop productivity (Table 4).

\section{Conclusions}

Our results show that enhancement of growth, biochemical and yield parameters of brinjal plant might be due to the presence of differential level of micro and macro elements, growth hormones, trace elements, vitamins, etc., in the liquid extracts of $S$. marginatum. Cytokinin and magnesium, which are considered as essential growth promoting constituents in chlorophyll biosynthesis might have played a key role in the enhancement of growth and physiology of brinjal. However, optimum concentration of seaweed liquid extracts is necessary as the present study exhibited that $1.5 \%$ SLE had better influence on growth and productivity of brinjal plants. It may be suggested that liquid seaweed extracts can be used as substitute for chemical fertilizers to improve the sustainable crop growth and yield. Further, the study also emphasizes that the application of seaweed liquid extracts of seaweeds can be effectively used as ecofriendly approach to organic farming.

Conflict of interest The authors declare that they have no competing interests.

Open Access This article is distributed under the terms of the Creative Commons Attribution 4.0 International License (http://creative commons.org/licenses/by/4.0/), which permits unrestricted use, distribution, and reproduction in any medium, provided you give appropriate credit to the original author(s) and the source, provide a link to the Creative Commons license, and indicate if changes were made.

\section{References}

Abdel-Mawgoud AMR, Tantaway AS, Hafez MM, Habib HAM (2010) Seaweed extract improves growth, yield and quality of different watermelon hybrids. Res J Agri Biol Sci 6(2):161-168 Ahmed MY, Sehrawy EL (2013) Effect of seaweed extract on fruiting of Hindy Bisinnara mango trees. J Amer Sci 9(6):539-544 
Anisimov MM, Chaikina EL, Klykov AG, Rasskazov VA (2013) Effect of seaweeds extracts on the growth of seedling roots of Buckwheat (Fagopyrum esculentum Moench) is depended on the season of algae collection. Agric Sci Dev 2(8):67-75

Arnon DI (1949) Copper enzymes in isolated chloroplasts, polyphenol oxidase in Beta vulgaris. Plant Physiol 24:1-15

Atzmon N, Van Staden J (1994) The effect of seaweed concentrate on the growth of Pinus pinea seedlings. New Forest 8(3):279-288

Bai NR, Mary Christi R, Christy Kala T (2013) Growth and yield characteristics of Dolichos biflorus Linn as influenced by seaweed liquid fertilizer. Plant Arch 13(1):163-166

Bhosle NB, Untawale AG, Dhargalkar VK (1975) Effect of seaweed extract on the growth of Phaseolus vulgaris L. Indian J Mar Sci 4:209-210

Blunden G, Jenkins T, Wan LY (1997) Enhanced leaf chlorophyll levels in plants treated with seaweed extracts. J Appl Phycol $8(6): 535-543$

Bozorgi HR (2012) Effects of foliar spraying with marine plant Ascophyllum nodosum extract and nano iron chelate fertilizer on fruit yield and several attributes of eggplant (Solanum melongena L.). ARPN J Agri Bio Sci 7(5):200-206

Duncan BD (1965) Multiple range and multiple test. Biometric $11: 1-42$

Durand N, Briand X, Meyer C (2003) The effect of marine bioactive substances (NPRO) and exogenous cytokinins on nitrate reductase activity in Arabidopsis thaliana. Physiol Plant 119:489-493

Erulan V, Soundrapandian P, Thirumaran G, Ananthan G (2009) Studies on the effect of Sargassum polycystum (C. Agardh. 1824) extract on the growth and biochemical composition of Cajanus Cajan (L.) Mill sp. Amer Eur J Agri Environ Sci 6:392-399

Eyras MC, Rostagno CM, Defosse GE (1998) Biological evaluation of seaweed composting. Comp Sci Util 6:74-81

Featonby-Smith BC, Van Staden J (1984) Identification and seasonal variation of endogenous cytokinin in Ecklonia maxima (Osbeck) Papen F. Bot Mar 17:527-531

Gordon SA, Paleg LG (1957) Quantitative measurement of indole acetic acid. Physiol Plant 10:37-48

Graham HD, Henderson JHM (1961) Reaction of gibberellic acid and gibberellins with Folin-Wu Phosphomolybdic acid reagent and its use for quantitative assay. Plant Physiol 36:405-408

Hernández-Herrera RM, Santacruz-Ruvalcaba F, Alberto Ruiz-López M, Norrie J, Hernández-Carmona H (2014) Effect of liquid seaweed extracts on growth of tomato seedlings (Solanum lycopersicum L). J Appl Phycol 26:619-628

Humpshires EC (1956) Mineral components and ash analysis. In: Rach K, Tracer MV (eds) Modern methods of Plant analysis. Springer-Verlag, Berlin, pp 468-502

Jaworski EG (1971) Nitrate reductase in intact plant tissue. Biochem Biophys Res Commun 43:1274-1279

Jothinayagi N, Anbazhagan C (2009) Effect of seaweed liquid fertilizer of Sargassum wightii on the growth and biochemical characteristics of Abelmoschus esculentus (L.) Medikus. Recent Res Sci Tech 1:155-158

Kalaivanan C, Chandrasekaran M, Venkatesalu V (2012) Effect of seaweed liquid extract of Caulerpa scalpelliformis on growth and biochemical constituents of black gram (Vigna mungo) (L.) Hepper. Phykos 42(2):46-53

Kalidass C, Jayarani S, Glory M (2010) Effect of seaweed liquid fertilizers on growth and biochemical constituents of Brassica nigra (L.). Intl J Agri Environ Biol 3:307-311

Khan W, Usha RP, Sowmyalakshmi S, Jithesh MN, Rayorath P, Hodges DM, Critchley AT, Craigie JS, Norrie J, Prithiviraj B
(2009) Seaweed extracts as biostimulants of plant growth and development. J Plant Growth Reg 28:386-399

Lowry OH, Rosebrough H, Farr AL, Randall RJ (1951) Protein measurement by folin-phenol reagent. J Biol Chem 193:265-275

Mooney PA, Van Staden J (1986) Algae and cytokinins. J Plant Physiol 123:1-21

Nelson N (1944) A photometric adaptation of Somogyis method for the determination of reducing sugar. Anal Chem 31:426-428

Ordog V, Stirk WA, van Staden J, Novak O, Strnad M (2004) Endogenous cytokinins in the three genera of macroalgae from the chlorophyta. J Phycol 40:88-95

Parthiban C, Saranya C, Hemalatha A, Kavitha B, Anantharaman P (2013) Effect of seaweed liquid fertilizer of Spatoglossum asperum on the growth and pigment content of Vigna radiata. Int J Recent Sc. Res 4(9):1418-1421

Pise NM, Sabale AB (2010) Effect of seaweed concentrates on the growth and biochemical constituents of Trigonella foenumgraecum. J Phytol 2(4):50-56

Roe JH (1954) Chemical determination of ascorbic, dehydroascorbic and diketogluconic acids. Meth Biochem Anal 1:115-139

Sanderson KJ, Jameson PE (1986) The cytokinins in a liquid seaweed extract: could they be the active ingredients? Acta Hort (ISHS) 179:113-116

Sasikumar K, Govindan T, Anuradha C (2011) Effect of seaweed liquid fertilizer of Dictyota dichotoma on growth and yield of Abelmoschus esculentus (L). Eur J Exp Biol 1:223-227

Sekar R, Thangaraju N, Rengasamy R (1995) Effect of seaweed liquid fertilizer from Ulva lactuca on Vigna unguiculata L. (Walp). Phykos 34:49-53

Siddagangaiah K, Raveesha A, Vasanth Kumar T (2010) Effect of foliar application of phyton- a seaweed extract on growth and yield of potato. Potato J 37(1-2):44-47

Sivasankari S, Chandrasekaran M, Kannathasan K, Venkatesalu V (2006) Studies on the biochemical constituents of Vigna radiata Linn treated with seaweed liquid fertilizer. Seaweed Res Utiln 28(1):151-158

Sridhar S, Rengasamy R (2010) Effect of seaweed liquid fertilizer on the growth, biochemical constituents and yield of Tagetes erecta under field trial. J. Phytol 2(6):61-68

Syono K, Torrey JG (1976) Identification of cytokinins of root nodules of the Garden Pea, Pisum sativum L. Plant Physiol 57:602-606

Thevanathan R, Anjana D, Dinamani DS, Bhavani ILG (2005) Studies on the impact of application of marine algal manure and liquid fertilizer in the linear growth of the seedlings of some pulses. Seaweed Res Utiln 27(1\&2):125-133

Thirumaran G, Arumugam M, Arumugam R, Anantharaman P (2009) Effect of seaweed liquid fertilizer on growth and pigment concentration of Cyamopsis tetrogonolaba (L.) Taub. Am Euras J Agron 2:50-56

Whapman CA, Blunden G, Jenkins T, Hankins SD (1993) Significance of betaines in the increased chlorophyll content of plants treated with seaweed extract. J Appl Phycol 5:231-234

Zodape ST, Kawarkhe VJ, Patolia JS, Warade AD (2008) Effect of liquid seaweed fertilizer on yield and quality of okra (Abelmoschus esculentus L.). J Sci Ind Res 67:1115-1117

Zodape ST, Mukhopadhyay S, Eswaran K, Reddy MP, Chikara J (2010) Enhanced yield and nutritional quality in green gram (Phaseolus radiata L.) treated with seaweed (Kappaphycus alvarezii) extract. J Sci Ind Res 69:468-471

Zodape ST, Gupta A, Bhandari SC (2011) Foliar application of seaweed sap as biostimulant for enhancement of yield and quality of tomato. J Sci Ind Res 67:215-219 